\title{
Molecular Characterization and Comparison of 38 Virulent and Temperate Bacteriophages of Streptococcus lactis
}

\author{
By PURIFICATION RELANO,${ }^{1}$ MIREILLE MATA, ${ }^{1}$ * MARC BONNEAU ${ }^{2}$ \\ AND PAUL RITZENTHALER ${ }^{1}$ \\ ${ }^{1}$ Centre de Transfert en Biotechnologie-Microbiologie, INSA, Avenue de Rangueil, \\ 31077 Toulouse Cédex, France \\ ${ }^{2}$ TRANSIA, 8 Rue Saint Jean de Dieu, 69007 Lyon, France
}

(Received 18 February 1987; revised 15 June 1987)

\begin{abstract}
Thirty-three virulent and five temperate phages of Streptococcus lactis and Streptococcus cremoris were differentiated into three groups by DNA homology. A complete lack of DNA homology was demonstrated between the phage groups. Within each group, large parts of the phage genomes were homologous except for a few phages. One group consisted of five temperate and two virulent phages suggesting that virulent phages isolated during abnormal fermentations and temperate phages isolated after induction from lactic streptococcal starter cultures may be related to one another. We observed a good correlation between the grouping of phages by DNA homology and by their protein composition since within the same DNA homology group, the protein composition of a phage exhibited some similarities with that of the other phages of the group. Therefore, the DNA homologies seemed to be located, at least, in the region coding for the structural proteins. By immunoblotting, we confirmed the relatedness between the proteins of the phages belonging to the same DNA homology group. The important host range factor in bacterium-phage interactions appeared to be an unreliable criterion in determining phage taxonomy.
\end{abstract}

\section{INTRODUCTION}

Lysis of lactic acid bacteria by bacteriophages remains a major problem in the dairy industry today, in spite of numerous studies over the last twenty years. Recently attempts have been made to develop phage resistant strains; nevertheless, a wider knowledge of phage biology seems to be indispensable to overcome the phage problem.

Differentiation of phages has been proposed on the basis of ultrastructure, serology and host range but the genomes of only a few phages have been characterized (Loof et al., 1983; ShimizuKadota et al., 1983). A more valid criterion of relatedness between phages is the degree of DNA homology since, unlike the other criteria, it takes into account the entire genome. Only a few phages of lactic acid bacteria have been compared by DNA-DNA hybridization: 25 lactic streptococcal bacteriophages were differentiated by DNA homology into four species by Jarvis $(1984 a, b)$. By Southern hybridization, Shimizu-Kadota et al. (1983) showed the prophage origin of a virulent phage appearing in fermentations of Lactobacillus casei S1. With the exception of this case, the source of the virulent phages, which appear during industrial fermentations, is still unknown. Some authors, for example Reyrolle et al. (1982), believe that virulent phages originate as temperate phages for lysogenic starter bacteria since they found a close correlation between the lytic spectra of temperate and virulent phages. This opinion is contested by Jarvis (1984a), who argues that the indicator strains for the temperate phages are rare and therefore lysogenic strains are of minor importance in the appearance of accidents in cheese making.

In the present study, we determined the relatedness between some virulent and temperate phages of Streptococcus lactis and Streptococcus cremoris using DNA-DNA hybridization. The 
different phages were also compared by their restriction patterns, their protein composition, their antigenic properties and their host range. Among the 38 phages used in the work, five act as temperate phages and were isolated by Huggins \& Sandine (1977). The virulent phages were isolated during abnormal fermentations in cheese making, and have different geographical origins (France, USA, Germany, Argentina and New Zealand).

\section{METHODS}

Bacterial strains and bacteriophages. These are listed in Tables 1 and 2. All strains were Streptococcus lactis or Streptococcus cremoris. They were maintained in M17 broth (Terzaghi \& Sandine, 1975). Temperate phages were designated by the method of Jarvis (1977), using the symbol $\phi$ followed by the letter $T$ and the number of the strain from which they were isolated.

Table 1. Temperate phages used in this work

These phages were isolated by Huggins \& Sandine (1977).

$\begin{array}{lll}\text { Phage } & \text { Propagating host } & \text { Lysogenic strains } \\ \phi \mathrm{T} 187 & \text { S. lactis } 205 & \text { S. cremoris } 187 \\ \phi \mathrm{T} 188 & \text { S. lactis } 205 & S \text {. cremoris } 188 \\ \phi \mathrm{T} 189 & \text { S. lactis } 205 & S \text {. cremoris } 189 \\ \phi \mathrm{TBK} 5 & \text { S. cremoris } \mathrm{H} 2 & S \text {. cremoris } \mathrm{BK} 5 \\ \phi \mathrm{TC} 2 & \text { S. cremoris } 1 \mathrm{~S} & \text { S. lactis } \mathrm{C} 2\end{array}$

Table 2. Virulent phages used in this work

\begin{tabular}{|c|c|c|}
\hline Phage & Propagating host & Source* \\
\hline Stll & S. lactis $\mathrm{C} 2$ & Parada et al. (1984) \\
\hline$\phi 27$ & S. lactis S13 & \\
\hline$\phi 28$ & S. lactis S14 & \\
\hline$\phi 29$ & S. lactis S15 & \\
\hline$\phi 30$ & S. lactis S16 & \\
\hline$\phi 31$ & S. lactis $\mathrm{S} 17$ & \\
\hline$\phi 39$ & S. lactis $\mathbf{S} 20$ & \\
\hline$\phi 41$ & S. lactis S18 & \\
\hline$\phi 44$ & S. lactis S24 & \\
\hline$\phi 45$ & S. lactis S35 & \\
\hline$\phi 49$ & S. lactis $\mathbf{S} 25$ & \\
\hline$\phi 54$ & S. lactis $\mathrm{S} 17$ & \\
\hline$\phi 55$ & S. lactis $\mathrm{S} 17$ & \\
\hline$\phi 56$ & S. lactis $\mathrm{S} 17$ & \\
\hline$\phi 57$ & S. lactis $\mathbf{S 1 7}$ & \\
\hline$\phi 58$ & S. lactis $\mathrm{S} 17$ & \\
\hline$\phi 42$ & S. lactis $\mathrm{S} 13$ & W. E. Sandine \\
\hline$\phi 59$ & S. lactis $\mathrm{C} 2$ & \\
\hline$\phi 61$ & S. cremoris $\mathrm{S} 11$ & \\
\hline$\phi 62$ & S. cremoris $\mathbf{S} 60$ & \\
\hline$\phi 63$ & S. cremoris S11 & \\
\hline$\phi 64$ & S. cremoris 187 & \\
\hline$\phi 65$ & S. cremoris $\mathbf{S} 3$ & \\
\hline$\phi 66$ & S. cremoris $\mathrm{S} 3$ & \\
\hline$\phi 67$ & S. cremoris $\mathrm{S} 61$ & \\
\hline$\phi 68$ & S. cremoris $\mathbf{S} 62$ & \\
\hline$\phi 69$ & S. cremoris S11 & \\
\hline$\phi 70$ & S. cremoris $\mathrm{S} 11$ & \\
\hline$\phi 936$ & S. cremoris 158 & Jarvis $(1984 a)$ via $\mathrm{H}$. W. Ackerman \\
\hline$\phi 1358$ & S. cremoris 582 & Jarvis $(1984 b)$ via H. W. Ackerman \\
\hline P008 & S. lactis 'subsp. diacetylactis' $\mathrm{F} 7 / 2$ & Engel et al. (1975) via H. W. Ackerman \\
\hline$\phi 40$ & S. cremoris S19 & \\
\hline$\phi 46$ & S. cremoris $\mathrm{S} 19$ & \\
\hline
\end{tabular}


Phage purification and preparation of phage DNA. This was done as described earlier for Lactobacillus lactis bacteriophage llh (Trautwetter et al, 1986).

DNA-DNA hybridization. Phage DNA was labelled by nick translation with $5^{\prime}-\left[\alpha^{-32} \mathrm{P}\right] \mathrm{dCTP}$ as described by Maniatis et al. (1982) and Rigby et al. (1977). Unlabelled phage DNA was digested with restriction endonuclease and the resulting fragments were separated by electrophoresis on a $1 \%(\mathrm{w} / \mathrm{v})$ agarose gel. The Southern blot technique (Southern, 1975) was used to transfer restriction fragments onto BA-85 nitrocellulose filter sheets (Schleicher and Schuell). Hybridization was done at $65^{\circ} \mathrm{C}$ for $40 \mathrm{~h}$. After hybridization, the filter was sequentially washed in: (1) $0.1 \% \mathrm{SDS} / \mathrm{salmon}$ sperm DNA $\left[50 \mu \mathrm{g} \mathrm{m}^{-1}\right.$ in $1 \times \mathrm{SSC}(1 \times \mathrm{SSC}$ is $0.15 \mathrm{M}-\mathrm{NaCl}$ plus $0.015 \mathrm{M}-$ sodium citrate) $] / 1 \times$ Denhardt solution (Denhardt, 1966) at $65^{\circ} \mathrm{C}$ for 1 min (four times) and for 45 min (three times); (2) salmon sperm DNA $\left(50 \mu \mathrm{g} \mathrm{ml}^{-1}\right) / 0 \cdot 1 \% \mathrm{SDS} / 0 \cdot 1 \times \mathrm{SSC}$ for $45 \mathrm{~min}$ at $65^{\circ} \mathrm{C}$ (three times); and (3) $3 \times$ SSC for $10 \mathrm{~min}$ at room temperature (twice). The filter was dried after the final wash and exposed to Kodak XAR film.

Antiserum production. Polyclonal rabbit antisera against phages were prepared as described by Mata et al. (1986).

Neutralization tests. Phage neutralization tests were carried out, and the rate of neutralization $(K)$ was determined as described by Adams (1959); phages (107 p.f.u. $\mathrm{ml}^{-1}$ ) and antiserum dilutions of $1: 50$ to $1: 10000$ were incubated for $15 \mathrm{~min}$ at $37^{\circ} \mathrm{C}$ and the percentage of surviving phages was determined.

SDS-PAGE. Purified phage particles containing approximately $0.05 \mathrm{mg}$ protein were suspended in a solution containing $0.06 \mathrm{M}$-Tris $/ \mathrm{HCl} \mathrm{pH} \mathrm{6.8,5 \% (v/v)} \mathrm{2-mercaptoethanol,} \mathrm{and} 2 \%(\mathrm{w} / \mathrm{v}) \mathrm{SDS}$, disrupted by boiling at $100{ }^{\circ} \mathrm{C}$ for $8 \mathrm{~min}$ and then electrophoresed in a slab gel $(12.5 \%, \mathrm{w} / \mathrm{v}$, acrylamide) as described by Laemmli (1970) and silver stained by the method of Oakley et al. (1980).

Western blotting and enzyme immunoassays. After electrophoresis, protein bands were electroblotted onto nitrocellulose paper by the method of Towbin et al. (1979) and blocked in $3 \%(\mathrm{v} / \mathrm{v})$ BSA in phosphate-buffered saline. Strips were then incubated for $2 \mathrm{~h}$ at $37^{\circ} \mathrm{C}$ with rabbit antiserum diluted $200 \times$. After rinsing, the paper strips were incubated for $1 \mathrm{~h}$ with horse-radish peroxidase-conjugated second antibody (goat anti-rabbit immunoglobulin: 1:1000 dilution). The substrate solution for the peroxidase contained $0.5 \mathrm{mg}$ 4-chloro-1-

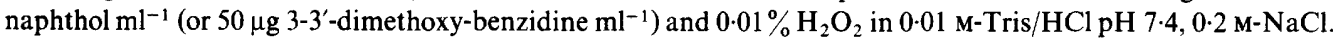

Dot-immunoblotting. Purified phage suspensions $(2 \mu \mathrm{l})$ were directly spotted onto a nitrocellulose filter. The discs were then treated as described above in Western blotting after the protein electroblotting.

\section{RESULTS}

Phages $\phi 936, \phi 1358$ and P008, whose genomes have been previously characterized (Jarvis $1984 a$, Loof et al., 1983), were included in the study as reference phages. All the purified phages were examined by electron microscopy. They showed no major variation in their morphology; all had the isometric polyhedral heads and tails normally observed for lactic streptococcal phages.

\section{Comparison of restriction endonuclease patterns of the phage DNAs}

DNA from each phage was digested with various restriction endonucleases. The DNAs were highly refractory to restriction by some endonucleases: they were not cleaved by $\operatorname{Sal}$ I, BamHI, $X h o I$, HindIII and PstI. Amongst the endonucleases used, only a few were able to cut the phage DNAs; AvaI, ClaI, EcoRI and EcoRV were especially active. Some phages shared similarities in their restriction pattern. The following phage pairs showed identical gel patterns after digestion with $E c o$ RI and $E c o \mathrm{RV}: \phi \mathrm{T} 187$ and $\phi \mathrm{T} 188 ; \phi 28$ and $\phi 29 ; \phi 39$ and $\phi 41 ; \phi 66$ and $\phi 67$. Phages $\phi 40$ and $\phi 46$ showed identical EcoRI digest patterns and differed by only one $E c o$ RV site. The gel patterns of $E c o$ RI digests of $\phi 44$ and $\phi 45$ were indistinguishable but only one common band was found after digestion with $E c o$ RV. The DNAs from phages $\phi 54, \phi 55$, $\phi 56$ and $\phi 57$ showed identical EcoRI digestion patterns but they differed in their EcoRV restriction patterns. All the other DNAs showed individual restriction endonuclease patterns, although some restriction fragments of identical size were found in several restriction patterns. For example, a $3.4 \mathrm{~kb} E c o \mathrm{RV}$ fragment was present in the restriction pattern of phages Stl1, $\phi 27, \phi 28, \phi 29, \phi 30, \phi 39, \phi 41$ and $\phi 44$. Also a band of $2 \mathrm{~kb}$ was common in all of the EcoRV digest patterns of phages $\phi 40, \phi 46, \phi 62$ to $\phi 66, \phi 68$ and $\phi 69$. Other comigrating restriction fragments could be detected in the restriction pattern of some phage DNAs. The genome size of each phage was given by the sum of the molecular sizes of restriction fragments generated by 


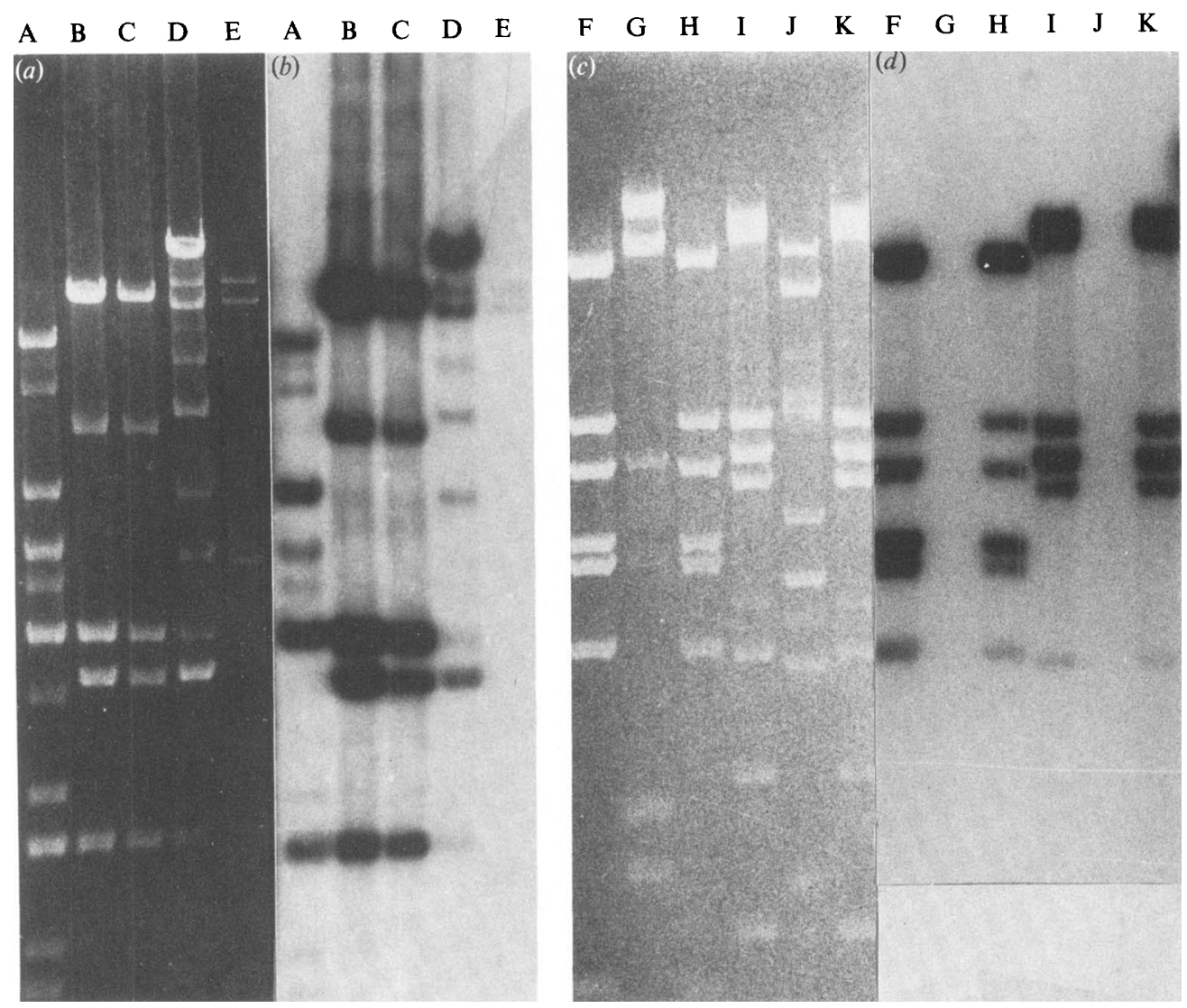

Fig. 1. (a), (c) Agarose gel electrophoresis of endonuclease digests of DNA phages; $(b),(d)$ Autoradiograms prepared after hybridization of ${ }^{32} \mathrm{P}$-labelled DNA from $\phi 28$ with DNA fragments. Lanes (restriction endonucleases used): A, $\phi 27$ (EcoRV); B, $\phi 28$ (EcoRV); C, $\phi 29$ (EcoRV); D, $\phi 30$ (EcoRV); E, $\phi 31$ (EcoRV); F, $\phi 39$ (EcoRI); G, $\phi 40$ (EcoRI); H, $\phi 41$ (EcoRI); I, $\phi 39$ (EcoRV); J, $\phi 40$ $($ EcoRV); K, $\phi 41($ EcoRV).

digestion with one endonuclease. The size of the different phage genomes were estimated to be between 20 and $57 \mathrm{~kb}$.

\section{DNA-DNA hybridization}

DNA from $\phi 28, \phi 42$, Stl1 and $\phi$ T189 was labelled with $\left[\alpha-{ }^{32}\right.$ P]dCTP by nick translation and each labelled DNA was used as a probe to hybridize to each phage DNA digested with EcoRI and $E c o$ RV. The resulting autoradiograms were compared with the digestion patterns to determine the number of bands to which the DNA probe had hybridized. This approach gives an estimation of the maximum DNA homology since a partial homology between the probe and the restriction fragment is sufficient to give rise to hybridization. Probe DNA from phage $\phi 28$ was able to hybridize to all the restriction fragments of $\phi 29, \phi 44, \phi 45, \phi 54, \phi 55, \phi 56$ and $\phi 57$ and to all except one restriction fragment of $\phi 27, \phi 39, \phi 41$ and $\phi 58$. This probe showed partial homology with DNA from $\phi 30$ (4 out of the 12 EcoRV fragments strongly hybridized to the probe).

Phages $\phi 31$ and Stll exhibited only weak homology with $\phi 28$, since respectively three out of the four and three out of the five EcoRI fragments of these phages hybridized weakly to the probe DNA from $\phi 28$ (Fig. 1). No homology was found with the other phages.

Labelled DNA from phage $\phi \mathrm{T} 189$ hybridized to restriction fragments from phages $\phi \mathrm{T} 187$, $\phi \mathrm{T} 188, \phi \mathrm{TBK} 5, \phi \mathrm{TC} 2, \phi 49$ and $\phi 42$. The homology between the probe and these phages was 
Table 3. Homology between ${ }^{32}$ P-labelled $\phi T 189$ DNA and unlabelled DNA of other phages

\begin{tabular}{|c|c|c|c|c|c|c|c|c|c|c|c|c|}
\hline & & & & & Size & estri & on $\mathrm{fr}$ & gments & $(\mathrm{kb})^{*}$ & & & \\
\hline$\phi \mathrm{T} 187$ & EcoRI & $\begin{array}{c}13.6 \\
+\end{array}$ & $\begin{array}{l}8 \cdot 6 \\
+\end{array}$ & $\begin{array}{l}4.8 \\
+\end{array}$ & $3 \cdot 4$ & 3 & $2 \cdot 6$ & 2 & $1 \cdot 8$ & & & \\
\hline$\phi \mathrm{T} 188$ & EcoRI & $\begin{array}{c}+ \\
13 \cdot 6 \\
+\end{array}$ & $\begin{array}{l}+ \\
8.6 \\
+\end{array}$ & $\begin{array}{l}+ \\
4 \cdot 8 \\
+\end{array}$ & $3 \cdot 4$ & $\begin{array}{l}+ \\
3 \\
+\end{array}$ & $\begin{array}{l}+ \\
2 \cdot 6 \\
+\end{array}$ & 2 & $1 \cdot 8$ & & & \\
\hline$\phi \mathrm{T} 189$ & $E c o \mathrm{RI}$ & $\begin{array}{c}13 \cdot 6 \\
+\end{array}$ & $\begin{array}{l}9 \\
+\end{array}$ & $\begin{array}{l}8 \\
+\end{array}$ & $\begin{array}{l}4 \cdot 6 \\
+\end{array}$ & $\begin{array}{l}4 \\
+\end{array}$ & $\begin{array}{l}2.8 \\
+\end{array}$ & $\begin{array}{l}2.5 \\
+\end{array}$ & $\begin{array}{l}2 \cdot 4 \\
+\end{array}$ & $\begin{array}{c}2 \\
(+)\end{array}$ & $\begin{array}{c}1.8 \\
(+)\end{array}$ & \\
\hline$\phi \mathrm{TC} 2$ & $E c o$ RI & $\begin{array}{c}10 \cdot 8 \\
+\end{array}$ & $\begin{array}{l}8 \cdot 1 \\
+\end{array}$ & $6 \cdot 8$ & $4 \cdot 2$ & & & & & & & \\
\hline$\phi$ TBK 5 & EcoRI & $\begin{array}{c}10 \cdot 8 \\
+\end{array}$ & $\begin{array}{l}8 \cdot 1 \\
+\end{array}$ & $6 \cdot 8$ & $4 \cdot 2$ & & & & & & & \\
\hline$\phi 42$ & EcoRV & $12 \cdot 8$ & $8 \cdot 6$ & $\begin{array}{l}6 \cdot 6 \\
+\end{array}$ & $\begin{array}{l}6 \cdot 2 \\
+\end{array}$ & $\begin{array}{l}4.8 \\
+\end{array}$ & $\begin{array}{l}3 \cdot 8 \\
+\end{array}$ & $2 \cdot 7$ & $\begin{array}{r}2 \cdot 4 \\
(+)\end{array}$ & $\begin{array}{r}1.5 \\
(+)\end{array}$ & & \\
\hline$\phi 49$ & Eco RI & $\begin{array}{c}12 \cdot 8 \\
+\end{array}$ & $\begin{array}{l}8 \cdot 6 \\
+\end{array}$ & $\begin{array}{l}5 \\
+\end{array}$ & $\begin{array}{l}4.8 \\
+\end{array}$ & $\begin{array}{l}4 \\
+\end{array}$ & $\begin{array}{l}3.7 \\
+\end{array}$ & $\begin{array}{r}2.7 \\
(+)\end{array}$ & $\begin{array}{r}2.8 \\
(+)\end{array}$ & $\begin{array}{r}2 \cdot 2 \\
(+)\end{array}$ & $\begin{array}{r}1 \cdot 4 \\
(+)\end{array}$ & $\begin{array}{c}1 \\
(+)\end{array}$ \\
\hline
\end{tabular}

* + , Strong hybridization; $(+)$, weak hybridization. When bands have no indication, no hybridization was detected.

complete for $\phi 49$, high for $\phi \mathrm{T} 187$ and $\phi \mathrm{T} 188$ and weak for $\phi 42, \phi \mathrm{TC} 2$ and $\phi \mathrm{TBK} 5$ (Table 3). Significant hybridization was not seen between any of the other phage DNA; however, a very weakly labelled band was detected by hybridization of $\phi \mathrm{T} 189$ to phages $\phi 61$ and $\phi 62$; this band was common to the two phages. This hybridization seemed to be too weak to be significant. Therefore, it appears that the DNA from 15 phages was able to hybridize to the $\phi 28$ probe and that from seven other phages was able to hybridize to the $\phi \mathrm{T} 189$ probe. The 16 remaining phages were analysed by hybridization of their DNA with phage $\phi 40$. Their DNA was able to hybridize to $\phi 40$ DNA, with the exception of phage $\phi 1358$. The homology between the phages and the probe was extensive or high, since in almost all cases, all the restriction bands hybridized to the probe. No homology was detected between phage $\phi 40$ DNA and the DNA from phages which hybridize to probe $\phi 28$ or $\phi \mathrm{T} 189$.

By DNA-DNA hybridization, phages can be differentiated into three groups: 15 phages (Stl1, $\phi 27$ to $\phi 31, \phi 39, \phi 41, \phi 44, \phi 45$ and $\phi 54$ to $\phi 58)$ constitute group I, group II is composed of seven phages $(\phi \mathrm{T} 187, \phi \mathrm{T} 188, \phi \mathrm{T} 189, \phi \mathrm{TBK} 5, \phi 42, \phi 49, \phi \mathrm{TC} 2)$ and group III is composed of 15 phages ( $\phi 40, \phi 46, \phi 59, \phi 61$ to $\phi 70, \mathrm{P} 008$ and $\phi 936)$. One phage ( $\phi 1358)$ does not belong to any of these groups.

In order to confirm this differentiation, two other probes were used. Radiolabelled DNA from phage Stll hybridized to DNA from all the phages in group I but hybridization did not occur with the DNA from the phages in the other groups. In addition, no hybridization was detected between DNA from phages of groups I and III and the labelled DNA from phage $\phi 42$ but this probe hybridized to the DNA from phages of group II.

\section{Host range determination}

The lytic activity of the phages was determined on 19 propagating hosts and lysogenic strains (S. lactis and $S$. cremoris) (Table 4). Five phages $(\phi 31, \phi \mathrm{T} 187, \phi \mathrm{T} 188, \phi \mathrm{TBK} 5, \phi \mathrm{TC} 2)$ were active only on their homologous strains. Phages $\phi 28, \phi 40, \phi 45$ and $\phi 46$ proved to be active against at least five strains. Phage $\phi 27$ had the largest host range since it formed clear plaques on eight strains among the 19 tested. Thus an identical DNA restriction pattern does not necessarily imply an identical host range. For example, phages having similar restriction patterns such as $\phi 44$ and $\phi 45$ or $\phi 39$ and $\phi 41$ had the same host range except for two strains. In contrast, phage $\phi 28$, identical to $\phi 29$ in its restriction pattern, had its own host range which was completely different from that of $\phi 29$. It is interesting that almost all of the phages showed different lytic activities. Phages belonging to group II had a very narrow host range. They attacked only one or two strains whereas the host range of phages from groups I and III was broader. Only one strain ( $S$. lactis 205) was sensitive to some phages from all three groups; five 


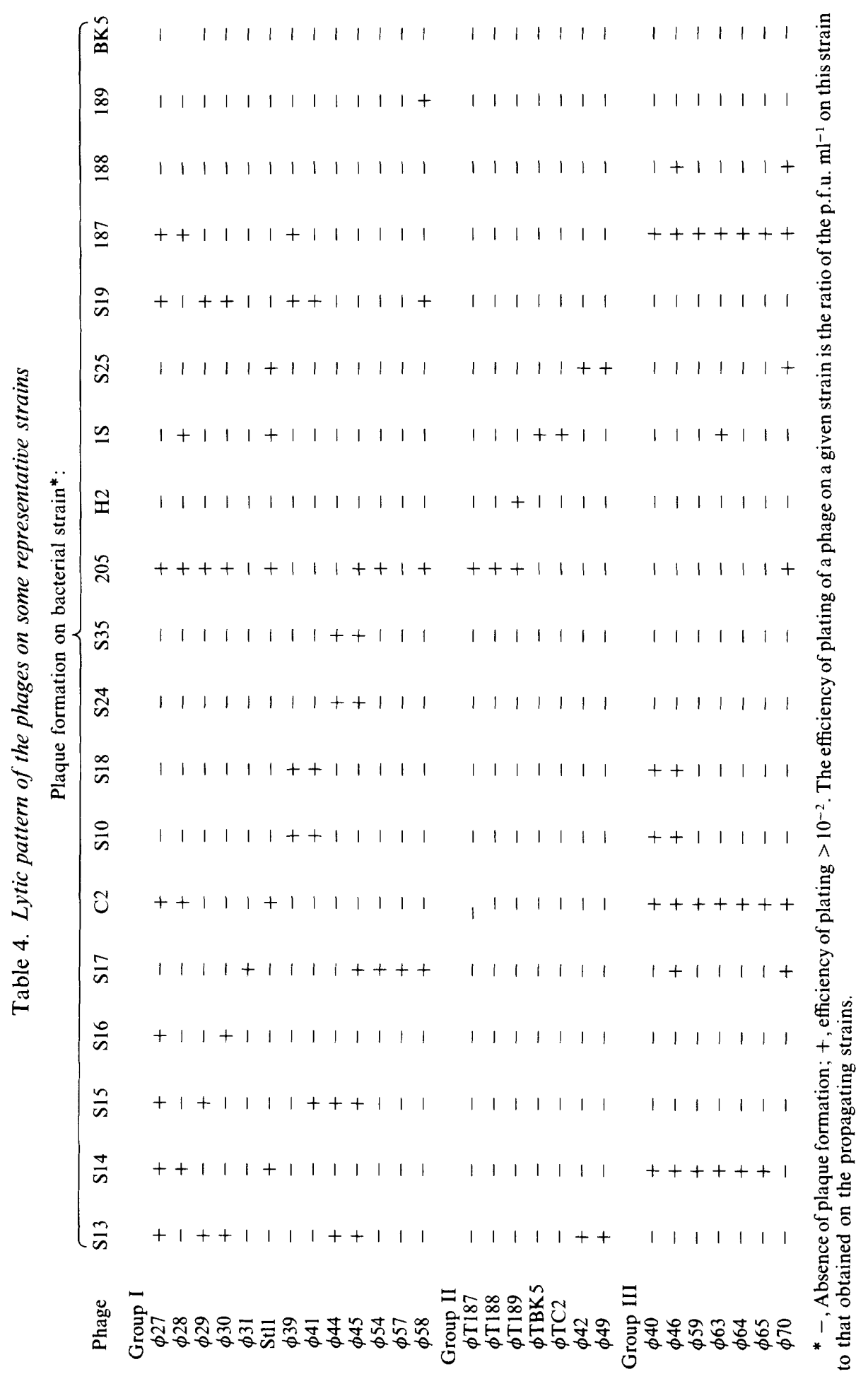




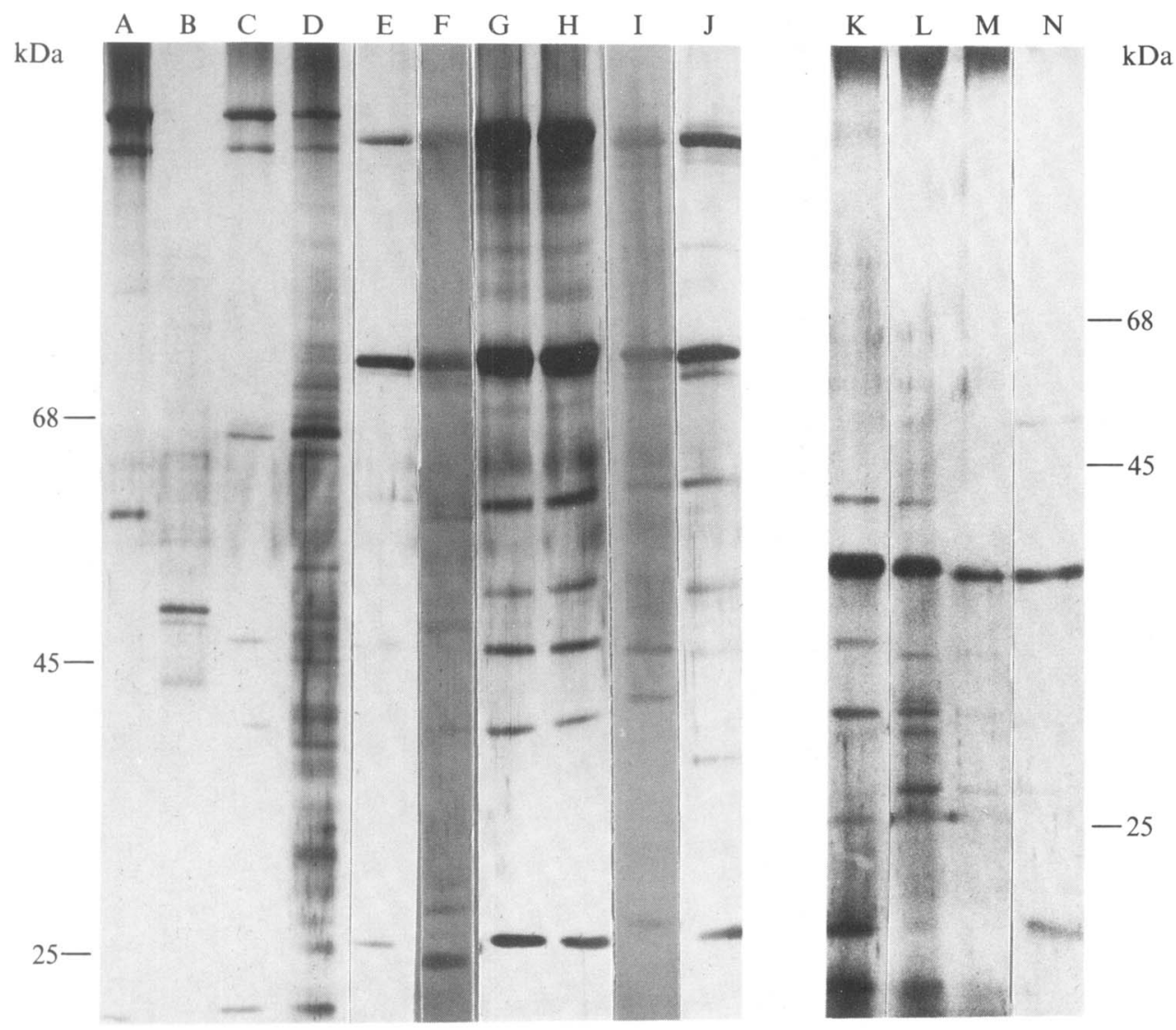

Fig. 2. Patterns of structural proteins of some phages by SDS-PAGE. Lanes: A, $\phi 42 ; \mathrm{B}, \phi \mathrm{TBK} 5$; C, $\phi \mathrm{T} 189 ; \mathrm{D}, \phi \mathrm{T} 187 ; \mathrm{E}, \phi 30 ; \mathrm{F}, \mathrm{Stl1} ; \mathrm{G}, \phi 41 ; \mathrm{H}, \phi 39 ; \mathrm{I}, \phi 28 ; \mathrm{J}, \phi 31 ; \mathrm{K}, \phi 40 ; \mathrm{L}, \phi 70 ; \mathrm{M}, \phi 936 ; \mathrm{N}, \mathrm{P} 008$. Molecular mass markers (kDa): chymotrypsinogen A (25); hen egg white albumin (45); and bovine serum albumin (68).

strains were sensitive to phages belonging to only one group and one lysogenic strain (BK5) was resistant to all the phages. Phages of group I which were isolated from $S$. lactis strains were also able to propagate on $S$. cremoris strains and conversely, phages of group III isolated from $S$. cremoris strains attacked $S$. lactis strains.

\section{Comparison of the protein composition of phage particles}

The structural proteins of some phages were analysed by SDS-PAGE. Within each group, the protein composition of each phage analysed presented some similarities with that of the other phages of the group. Phages of group I seem to be closely related in their protein composition. All of them contained some common minor proteins and three major proteins with estimated molecular masses of 115,78 and $27 \mathrm{kDa}$. All the phages of group II except phages $\phi$ TBK 5 and $\phi \mathrm{TC} 2$ possessed three major proteins with molecular masses of 119,113 and $23 \mathrm{kDa}$. The $23 \mathrm{kDa}$ molecular mass protein seems to be a compound of the tail since in phage preparations devoid of tail, this protein disappeared from the gel pattern. Phage $\phi$ TBK 5 did not possess the three major proteins present in the other phages of group II whereas phage $\phi \mathrm{TC} 2$ contained the $23 \mathrm{kDa}$ molecular mass protein. Therefore, phage $\phi$ TBK 5 appears to be the most atypical phage of group II. The protein composition of some phages of group III (phages $\phi 40, \phi 46, \phi 61, \phi 62$, $\phi 70, \phi 936$ and P008) was also analysed and this appeared to be completely different to that of the other groups. They all possess a major protein of $37 \mathrm{kDa}$ (Fig. 2). 
Table 5. Rates of neutralization of some phages of the three groups by antisera representing each DNA homology group

\begin{tabular}{|c|c|c|c|c|}
\hline \multirow[b]{2}{*}{ Phage } & \multirow[b]{2}{*}{ Group } & \multicolumn{3}{|c|}{$\begin{array}{l}\text { Rate of neutralization }(K, \%)^{*} \\
\text { in the presence of antiserum against phage: }\end{array}$} \\
\hline & & $\begin{array}{c}\phi 31 \\
\text { (group I) }\end{array}$ & $\begin{array}{c}\phi \mathrm{T} 187 \\
\text { (group II) }\end{array}$ & $\begin{array}{c}\phi 40 \\
\text { (group III) }\end{array}$ \\
\hline$\phi 27$ & I & 11 & 0 & 0 \\
\hline$\phi 28$ & I & 8 & 0 & 0 \\
\hline$\phi 29$ & I & 0 & 0 & 1 \\
\hline$\phi 30$ & I & 22 & 0 & 0 \\
\hline$\phi 31$ & I & 100 & 1 & 0 \\
\hline$\phi 39$ & I & 0 & 0 & 0 \\
\hline$\phi 41$ & I & 0 & 0 & 0 \\
\hline$\phi 44$ & I & 0 & 0 & 0 \\
\hline$\phi 45$ & I & 0 & 0 & 0 \\
\hline Stll & I & 9 & 1 & 2 \\
\hline$\phi \mathrm{T} 187$ & II & 0 & 100 & 0 \\
\hline$\phi \mathrm{T} 188$ & II & 0 & 100 & 5 \\
\hline$\phi \mathrm{T} 189$ & II & 0 & 100 & 0 \\
\hline$\phi$ TBK 5 & II & 0 & 0 & 0 \\
\hline$\phi 42$ & II & 0 & 0 & 1 \\
\hline$\phi 49$ & II & 0 & 0 & 0 \\
\hline$\phi 40$ & III & 0 & 8 & 100 \\
\hline$\phi 46$ & III & 0 & 7 & 100 \\
\hline
\end{tabular}

* The $K$ value of an antiserum against homologous phage is $100 \%$.

\section{Neutralization of phages by antisera}

Antisera to phages $\phi 31, \phi \mathrm{T} 187$ and $\phi 40$, each belonging to one of the three different groups, were prepared and tested against several phages for phage neutralization antibodies (Table 5). Of the 10 phages of group I tested, only five reacted with antiserum to phage $\phi 31$. Phages in groups II and III did not react with type I antiserum. Similar results were observed for the neutralization of phages of group II by type II antiserum: only the homologous phage $\phi \mathrm{T} 187$ and phages $\phi \mathrm{T} 188$ and $\phi \mathrm{T} 189$ were strongly neutralized by antiserum prepared against phage $\phi \mathrm{T} 187$. Similarly, phages $\phi 40$ and $\phi 46$, which belong to group III, were completely neutralized by the type III antiserum. Thus only a few phages were neutralized by antiserum prepared against a phage belonging to the same DNA homology group. In a few cases, type II and III antisera were able to weakly cross-react with some phages of the three groups.

\section{Determination of serological relationship between the phages by dot blotting and Western blotting}

Purified phages were spotted directly onto nitrocellulose strips and submitted to an ELISA test with antisera to three phages representative of the three groups. As expected, all of the phages belonging to the same DNA homology group reacted strongly with antiserum to the phage representative of the group. In some cases, as observed for phage neutralization by these antisera, some cross-reactions were also detected. For example, phages $\phi 42, \mathrm{P} 008$ and $\phi 67$ crossreacted with type I, II and III antisera.

In order to determine which phage proteins reacted with the antisera, some phages of groups I and II were also analysed by Western blotting. The proteins of some phages were separated by gel electrophoresis and submitted to immunoblotting tests with antisera to phages $\phi 31$ (group I) and $\phi \mathrm{T} 187$ (group II). When the proteins of group I phages were subjected to immunoblotting with polyclonal rabbit antiserum to phage $\phi 31$, eight protein bands (six intense and two weak bands) were found for phage $\phi 31$; among these eight proteins, at least six were also detected for phages $\phi 28, \phi 30, \phi 39, \phi 41$ and $\phi 45$. There was no strict correlation between the intensity of 


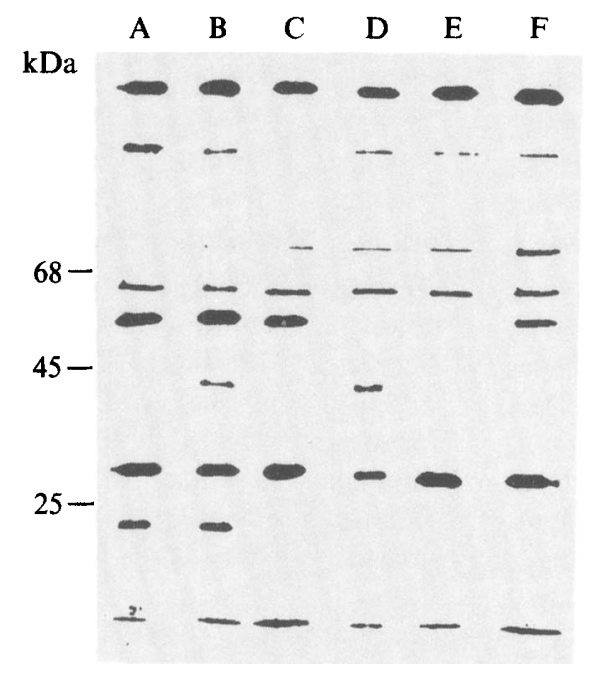

Fig. 3. Immunological identification of group I phage antigens after blot transfer using a rabbit antiserum to phage $\phi 31$ (group I). The phage proteins were subjected to SDS-PAGE, transferred to nitrocellulose and treated with the antiserum. The peroxidase substrate was 4-chloro-1-naphthol. Lanes: A, $\phi 39 ; \mathrm{B}, \phi 31 ; \mathrm{C}, \phi 45 ; \mathrm{D}, \phi 30 ; \mathrm{E}, \phi 28 ; \mathrm{F}, \phi 41$. Molecular mass markers as in Fig. 2.

bands detected in silver stained gels and those which were revealed by immunoblotting. In some cases, bands which were only weakly silver stained, such as the $56 \mathrm{kDa}$ and $23 \mathrm{kDa}$ molecular mass proteins, appeared as intense bands after immunoblotting analysis (Fig. 3). In the immunoblotting performed with antiserum to phage $\phi \mathrm{T} 187$, six proteins of this phage were revealed with approximate molecular masses of $119 ; 80 ; 69 ; 58 ; 47$ and $37 \mathrm{kDa}$. Only one of these proteins was also detected in phages $\phi \mathrm{T} 189, \phi \mathrm{TBK} 5, \phi \mathrm{TC} 2$ and $\phi 42$ (data not shown).

\section{DISCUSSION}

The 38 phages studied in this work are virulent or temperate phages of $S$. lactis and $S$. cremoris and have various geographical origins (France, USA, New Zealand, Germany and Argentina). The temperate phages came from lactic streptococcal starter cultures used in the USA. These phages were classified on the basis of their DNA homology by the Southern blot technique. Despite their different origin, they were differentiated into three DNA homology groups. Group I contained 15 phages and groups II and III contained respectively 7 and 15 phages. One phage $(\phi 1358)$ isolated in New Zealand and studied by Jarvis (1984a) did not belong to any of these groups. Groups I and III consisted of virulent phages whereas group II contained both virulent and temperate phages (five temperate and two virulent phages). One virulent phage $(\phi 49)$ showed extensive DNA homology with the temperate phages. This result contrasts with that described by Jarvis $(1984 b)$ in a study showing a lack of DNA homology between the DNA from 25 lytic phages and three temperate phages of $S$. cremoris. In both investigations, the temperate phage $\phi$ TBK 5 was included. In a previous report (Mata et al., 1986), we showed partial DNA homology between temperate and virulent phages of Lactobacillus lactis and Lactobacillus bulgaricus. The demonstration of a relatedness between virulent and temperate phages has technological importance since it is not yet known whether the virulent phages isolated during abnormal industrial fermentations originate as temperate phages from lysogenic bacteria used in starter cultures or as lytic phages from external sources. The DNA homologies between virulent and temperate phages do not definitively prove that temperate phages might be a source of virulent phages in industrial fermentations; however, the relatedness between virulent and 
temperate phages indicates that they may have identical phage ancestors. Shimizu-Kadota et al. (1983) demonstrated the prophage origin of a virulent phage appearing in fermentation of $L$. case $\mathrm{S} 1$ and were able to prevent the appearance of this virulent phage by using a prophagecured derivative of $\mathrm{S} 1$.

Phage P008, which is widespread in German cheese factories, and phage $\phi 936$, isolated in New Zealand, showed strong DNA homologies with some virulent phages isolated in France and were included in group III. Jarvis (1984a) showed that DNA from phage $\phi 936$ was able to hybridize to DNA from nine phages. These phages constituted type $a$ species in the classification proposed by Jarvis. Probably, our group III and type $a$ described by Jarvis constitute a unique phage species. Within groups I and III, the DNA homologies between the different phages were extensive. However, phages Stll and $\phi 31$, which belong to group I, showed less DNA homology with the probe than the other phages of the group. Within each DNA homology group, the phages exhibited some similarities in their protein composition. All of them possessed, at least, the same major proteins except phages $\phi \mathrm{TBK} 5$ and $\phi \mathrm{TC} 2$, which also only weakly hybridized to the $\phi \mathrm{T} 187$ probe. Thus these two phages are the least representative phages of group II.

The DNA homologies seem to be located at least in the chromosomal region coding for the structural proteins. Within the same DNA homology group, almost all the phages may possess similar 'modules' (Botstein, 1980) coding for the structural proteins of the head and the tail. Botstein (1980), in his theory of modular evolution for bacteriophages, supposes that genetic elements (modules) can be exchanged by homologous recombination. This theory could explain the great flexibility of the phages, their adaptation to a new environment and the close relatedness of the phages isolated in the dairy industry.

We observed a good correlation between grouping phages by DNA homology and by their protein composition. In contrast, the host range - in spite of its practical importance - is an unreliable criterion for the study of phage taxonomy. On the one hand, the efficiency of plating on a bacterial strain depends on interactions between the phage and the bacterium and therefore can involve several mechanisms independent of the phage. On the other hand, a single mutation which does not alter the DNA homology grouping of the phage can change the host range of a phage. These reasons could explain why the host range does not correlate with relatedness at the DNA level. For example, phages which have the same restriction patterns and $100 \%$ DNA homology, such as $\phi 28$ and $\phi 29$, have completely different lytic spectra. The contrary also occurred : phages having approximately the same host range, such as $\phi 39$ and $\phi 40$ or $\phi 28$ and $\phi 63$, showed a complete lack of DNA homology. Phages from group II, unlike those of groups I and III, had a very narrow host range. This result is not surprising since this group is essentially composed of temperate phages and it has been shown that bacteria acting as propagating hosts for temperate phages are rare. Phages of groups I and III were not bacterial species specific: they are able to attack $S$. cremoris as well as $S$. lactis strains.

A correlation was demonstrated between immunoblotting analysis and bacteriophage seroneutralization but the immunoblotting analysis was more sensitive than the seroneutralization analysis. An absence of relatedness by means of seroneutralization does not necessarily imply an absence of homology in their genomes since not all the phages were sensitive to seroneutralization.

DNA from all the phages was not cut by many endonucleases. This has been observed for other phages of group N lactic streptococci (Loof et al., 1983; Powell \& Davidson, 1986). Loof et al. (1983) explain this behaviour as an evolutionary response of the phage to the presence of a variety of restriction-modification systems in host strains. In contrast, phages of L. bulgaricus and $L$. lactis isolated during abnormal fermentations were digested by numerous endonucleases (Mata et al., 1986).

This work was supported by grants from the Centre National de la Recherche Scientifique (LP 8201, ATP 'Biotechnologies orientées vers l'Industrie') and from the Ministère de la Recherche et de la Technologie.

We thank W. Sandine, J. L. Parada and H. W. Ackerman for providing some strains and phages; J. C. Morel Guillemaz for technical assistance and M. C. Haugh for reading the manuscript. 


\section{REFERENCES}

ADAMS, M. H. (1959). Bacteriophages, New York: Interscience.

Botstein, D. (1980). A theory of modular evolution for bacteriophages. Annals of the New York Academy of Sciences 354, 484-491.

DENHARDT, D. T. (1966). A membrane filter technique for the detection of complementary DNA. Biochemical and Biophysical Research Communications 23, 641-646.

Engel, G., Milczewski, K. E. \& LembKe, A. (1975). Versuche zur Differenzierung von Phagen der Streptococcus lactis und cremoris Gruppe: Bakterienspektrum, serologische und morphologische Kriterien. Kieler Milchwirtschaftliche Forschungsberichte $27,25-48$.

Huggins, A. R. \& SANDine, W. E. (1977). Incidence and properties of temperate bacteriophages induced from lactic streptococci. Applied and Environmental Microbiology 33, 184-191.

JARVIS, A. W. (1977). The serological differentiation of lactic streptococcal bacteriophage. New Zealand Journal of Dairy Science and Technology 12, 176-181.

JARVIS, A. W. (1984a). Differentiation of lactic streptococcal phages into phage species by DNADNA homology. Applied and Environmental Microbiology 47, 343-349.

JARVIS, A. W. (1984b). DNA-DNA homology between lactic streptococci and their temperate and lytic phages. Applied and Environmental Microbiology 47, 1031-1038.

LAEMMLI, U. K. (1970). Cleavage of structural proteins during the assembly of the head of bacteriophage T4. Nature, London 227, 680-685.

Loof, M., LembKe, J. \& Teuber, M. (1983). Characterization of the genome of the Streptococcus lactis 'subsp. diacetylactis' bacteriophage P008 widespread in German cheese factories. Systematic and Applied Microbiology 4, 413-423.

Maniatis, T., Fritsch, E. F. \& Sambrook, J. (1982). Molecular Cloning: a Laboratory Manual. Cold Spring Harbor, NY: Cold Spring Harbor Laboratory.

Mata, M., Trautwetter, A., Luthaud, G. \& RitzenthaleR, P. (1986). Thirteen virulent and temperate bacteriophages of Lactobacillus bulgaricus and Lactobacillus lactis belong to a single DNA homology group. Applied and Environmental Microbiology 52, 812-818.

OAKLEY, B. R., KIRSCH, D. R. \& MORRIS, N. R. (1980). A simplified ultrasensitive silver stain method for detecting proteins in polyacrylamide gel. Analytical Biochemistry 105, 361-363.

Parada, J. L., La Via, M. I. \& Solari, A. J. (1984). Isolation of Streptococcus lactis bacteriophages and their interaction with the host cell. Applied and Environmental Microbiology 47, 1352-1354.

Powell, I. B. \& Davidson, B. E. (1986). Resistance to in vitro restriction of DNA from lactic streptococcal bacteriophage c6A. Applied and Environmental Microbiology 51, 1358-1360.

Reyrolle, J., Chopin, M. C., Letellier, F. \& Novel, G. (1982). Lysogenic strains of lactic acid streptococci and lytic spectra of their temperate bacteriophages. Applied and Environmental Microbiology 43, 349-356.

Rigby, P. W., Dieckmann, M., Rhodes, C. \& Berg, P. (1977). Labelling deoxyribonucleic acid to high specific activity in vitro by nick translation with DNA polymerase I. Journal of Molecular Biology 113, 237-251.

Shimizu-Kadota, M., Sakurai, T. \& Tsuchida, N. (1983). Prophage origin of a virulent phage appearing in fermentations of Lactobacillus casei $\mathrm{S} 1$. Applied and Environmental Microbiology 45, 669-674.

SOUTHERN, E. M. (1975). Detection of specific sequences among DNA fragments separated by gel electrophoresis. Journal of Molecular Biology 98, 503-517.

TERZAGHi, B. E. \& SANDine, W. E. (1975). Improved media for lactic streptococci and their bacteriophages. Applied and Environmental Microbiology 29, 807-813.

Trautwetter, A., Ritzenthaler, P., Alatossava, T. \& MATA-Gilsinger, M. (1986). Physical and genetic characterization of the genome of Lactobacillus lactis bacteriophage llh. Journal of Virology 59, 551-555.

Towbin, H., Staehelin, T. \& GoRdon, J. (1979). Electrophoretic transfer of proteins from polyacrylamide gels to nitrocellulose sheets: procedure and some applications. Proceedings of the National Academy of Sciences of the United States of America 76, 4350-4354. 